\title{
Risk and prevention of Chinese film crowdfunding mode
}

\author{
Xiancai Zhang \\ School of Communication, Yunnan Normal University \\ Kunming 650500, China \\ 1073479599@qq.com
}

\begin{abstract}
The combination of crowdfunding and film industry alleviates the problems of difficult and expensive financing in traditional film industry and effectively promotes the development of medium and small film industry. However, while crowdfunding films are developing rapidly, there are also legal regulatory risks, operational management risks, credit risks and other unknown risks. Based on the risks faced by film crowdfunding, this paper puts forward Suggestions on risk prevention from multiple perspectives to promote the healthy development of film industry crowdfunding.
\end{abstract}

\section{Keywords_Films; Crowdfunding; Risk prevention}

Crowdfunding, also known as crowdfunding, means that project sponsors present their creative projects to the public through the Internet crowdfunding platform, and strive for public support, so as to achieve the purpose of raising funds [1].The low threshold, diversity and emphasis on creativity of crowdfunding make Internet finance integrated into all walks of life.Film crowdfunding breaks through the traditional film financing mode, enabling ordinary audiences to invest in films and injecting a new force into the development of the film industry.The mode of crowdfunding overturns the high cost barrier of traditional films, allocates the production cost in group behavior, and reduces the investment risk of films.At the same time, the film crowdfunding also USES Internet data to preheat the consumer market in the early stage of the film.As one of the manifestations of sharing economy, crowdfunding can achieve everyone's participation through sharing platforms.

\section{THE DEVELOPMENT STATUS OF CHINESE FILM CROWDFUNDING}

Film crowdfunding started late in China and is still in the primary stage of development in China.From 2011 to 2013, film crowdfunding began to develop slowly in China.Since 2014, alibaba, baidu and other platforms have successively entered the film crowdfunding market.In 2015, thanks to the overall prosperity of the national box office market and the success of the Monkey King: journey to the west, crowdfunding platforms for films increased rapidly.Since 2016, due to the tightening of crowd-funding policies, the film crowd-funding financing mode has entered a constant development.At present, the film crowdfunding in China is mainly dominated by online big films and online micro films with low cost, while the scale of crowdfunding is small.The financing mode of film crowdfunding can be divided into four categories: reward crowdfunding, stock crowdfunding, debt crowdfunding and public welfare crowdfunding.In 2013, 100,000 bad jokes launched crowdfunding at "roll call time" and became the first crowdfunding film released in China. Subsequent crowdfunding films include big fish and begony, the return of the Monkey King from journey to the west, overheard 3, the hypnotist, see you tomorrow, etc.The continuous development of crowdfunding is mainly because compared with the traditional financing mode, crowdfunding has advantages in exploiting new capital resources, reducing investment and financing costs and obtaining more market resources [2].However, the crowdfunding mode of Chinese films is still in its development stage, which brings opportunities to the film industry but also brings many limitations and risks.For example, the crowdfunding launched by zhongchou.com for micro films when youth meets dreams and wings ended in failure. Although the golden age was successful in the fundraising stage, the final box office was far from what was expected..

\section{THE RISKS OF CHINESE FILM CROWDFUNDING}

The financing mode of Chinese film crowdfunding has limitations such as small overall scale of financing, small amount of single film financing, non-standard crowdfunding platform and imperfect operation mechanism of crowdfunding, as well as legal supervision risk, operation and management risk, intellectual property risk and other unknown risks and benefits.

\section{A. Legal supervision risk}

At present, the operation and management of Chinese film crowd-funding platforms are still chaotic, and the definition of equity-based crowd-funding and illegal financing in Chinese laws is not clear, so people's understanding of film creation crowd-funding is still chaotic.Starting from the initiation of crowdfunding, there are many links involved in the process. The sponsors of crowdfunding may break laws in many links. The most important risk is that crossing the line of crowdfunding is defined as illegal fund-raising [2].According to the purpose and performance of crowdfunding, it may involve the crime of illegally absorbing public deposits and fund-raising fraud.Such as wang baoqiang's debut novel "uproar in India" was involved in a crowdfunding scam.The legal risk involved in equity-based crowdfunding is mainly the illegal issuance of shares.At present, most equity-based crowdfunding platforms in China fail to meet the requirements stipulated by relevant laws: non-public issued shares and equity transfer must submit an application for share offering to the securities administration department of the state council [3].At the same time, the crowdfunding platform is to conduct crowdfunding by showing the originality and feasibility of the project. If the ideas of others are copied arbitrarily, intellectual property infringement will occur.This will make the sponsors have a great legal risk.. 


\section{B. Operation management risk}

First, in the process of film crowdfunding.Low barriers to entry and high risks.At present, many fund raising sponsors and investors do not pay enough attention to the specific operation process and potential risks of film crowdfunding, which leads to the lack of creative ideas and rough production process, increasing the risk of failure of film crowdfunding.Film crowdfunding is not scientific.Many film crowdfunding projects are started by freelancers and film enthusiasts, who are not equipped with professional crowdfunding planning ability.Crowdfunding is relatively simple and ineffective.At present, China's film crowdfunding mode is mainly based on pre-purchase and incentive crowdfunding.Comparatively speaking, the United States has a more diversified crowdfunding mode. Different financing modes can be used for different films, which is conducive to the crowdfunding of films.Moreover, there are no strict operating standards for Chinese film crowdfunding, which will cause chaos in the operation of film crowdfunding if it is not cured in time.

\section{Credit risk}

With the rapid development of economy, all walks of life have attached great importance to integrity, in the process of the suggests, appeared a lot of people, carrying with it the financing for investors to question was the attitude of good faith of the raised platform, thus the credit risk, making the Internet the raised platform appear the situation of the financing difficulty, and seriously harm the interests of investors.For fund-raisers, they are also faced with credit risks. In the process of film crowdfunding, fundraising platforms and project sponsors cannot be excluded from seeking personal gains.In addition, crowdfunding platforms are also faced with credit risks. In the process of crowdfunding fund operation and transfer, the lack of special fund custody department will also cause credit risks.

\section{D. unknown risks and benefits}

As a financial behavior, crowdfunding should have a clear return model and predictable risks, but the current film crowdfunding model is not mature, and there are many risks that cannot be estimated.In addition, some crowdfunding projects have accumulated high popularity and high funds in a short time, but are doomed to a low box office.For example, 2014's golden age was successful in the fundraising stage, but the final box office of 50 million yuan was far from the estimated box office of 200 million yuan, which became a typical failure case of film crowdfunding.Real yields are also low for fund-raisers."If you're involved in crowdfunding a film, it's best not to have a profit-making mentality," one filmmaker told reporters.[4] crowdfunders can hardly get real economic benefits.

\section{SUGGESTIONS ON RISK PREVENTION OF CHINESE FILM CROWDFUNDING MODE}

The risk of film crowdfunding is relatively high, so attention should be paid to preventing risks in the whole process of crowdfunding.The risk prevention of film crowdfunding includes perfecting the construction of relevant legal system, improving the level of operation and management, constructing the credit system and raising the awareness of risk prevention.

\section{A. Improve the construction of relevant legal systems}

Film the suggests should strictly abide by the laws and regulations, and although on April 20, 2015 to submit amendments to the "securities law", July 18, 2015 units of the guiding opinions on promoting the healthy development of the Internet financial raise formulated the industry standard for all the regulations, but there are many practice problems, no specific measures for its implementation.At present, there are still many laws and regulations to be improved. First, Internet laws and regulations need to be improved to strengthen the management of Internet environment and curb illegal behaviors by legal means.Secondly, laws and regulations related to crowdfunding need to be improved. Inclusive laws and regulations that can regulate the scope of crowdfunding and prevent the risks of crowdfunding without restricting the development of crowdfunding should be formulated.In terms of intellectual property rights, initiators should strengthen the awareness of intellectual property rights protection, and should promptly find projects that imitate others' product ideas and contents.Attaching importance to confidential technology, product information and other aspects can reduce the risk of intellectual property rights.

\section{B. Improve operation management level}

Before the operation of crowdfunding, it is necessary to have a comprehensive understanding of the market status, carefully design the movie script, carefully write the crowdfunding copywriting, clarify the crowdfunding objectives, and formulate a scientific and rigorous crowdfunding plan.As for the low entry threshold of film crowdfunding, it is necessary to appropriately raise the entry threshold of film crowdfunding, strictly control the quality of projects, and reduce the risk of film crowdfunding.In the operation of crowd funding, more professional talents should be recruited to improve the scientificity and capability of the operation of crowd funding.At the same time, China's film crowdfunding mode should be enriched, and the appropriate financing mode should be selected to do a good job in the later period of service.Formulate clear management plans before, during and after the operation of crowdfunding to improve the operation and management level of film crowdfunding.

\section{Construct a credit system}

In film crowdfunding, credit risk is particularly important. If the credit risk is not solved, it will seriously affect the development of film crowdfunding.In the current environment, to prevent risks in a more reasonable and effective way, it is necessary to establish an innovative credit review mechanism.Valuable information should be mined and combined with traditional information.After the information of the database is integrated and analyzed, an effective credit audit mechanism is constructed to reduce the credit risk of investors and ensure the safety of investors' funds.At the same time, the security construction of the Internet and the operation business of Internet finance should be paid more attention to, and the regulation of crowdfunding should be further strengthened in combination with the way of crowdfunding financing returns.Secondly, it is necessary to promote the publicity of the credit investigation system and strengthen the effective connection with the crowdfunding platform, so as to further improve the default cost of the crowdfunding platform [5].Encouraging 
credit information sharing among crowdfunding platforms can effectively reduce the overall credit risk of the industry.

\section{Raise awareness of risk prevention}

The film industry itself is characterized by high risks and high returns. As a commodity and artwork, there are many risks that are difficult to estimate.This requires fundraisers and investors to improve their awareness of risk prevention in the crowdfunding process.There are so many stages of crowdfunding that a little carelessness may trigger some risks.In the process of crowdfunding, fundraisers should pay special attention to legal risks and check the quality of projects. Investors should also fully understand the quality of projects and verify the credibility of fundraising platforms and fundraisers.In addition, how to add investors' income, the current rate of return is very low, which will discourage investors to participate in the enthusiasm, seriously affect the development of film crowdfunding.

\section{REFERENCES}

[1] Zhu jiawei. Crowdfunding film financing mode and risk analysis [J]. Operation and management,2018(11):17-21.

[2] Chen yuwei. Research on film crowdfunding mode and development strategy [D]. China film art research center,2017.

[3] Zeng xiaoyan. Analysis on the risk and prevention of crowdfunding [J]. Contemporary economy,2018(21):38-39.

[4] Li junna. Film crowdfunding: fire rises high when people gather wood [N]. Liberation daily, 2015-08-17.

[5] Ren xiaocong, he jun. Status quo, problems and Suggestions for further development of crowdfunding in China [J]. Theoretical exploration.2016(02). 